\title{
SIPOS-KOVÁCS Marianna
}

\section{Az oktatás gazdasági értékei}

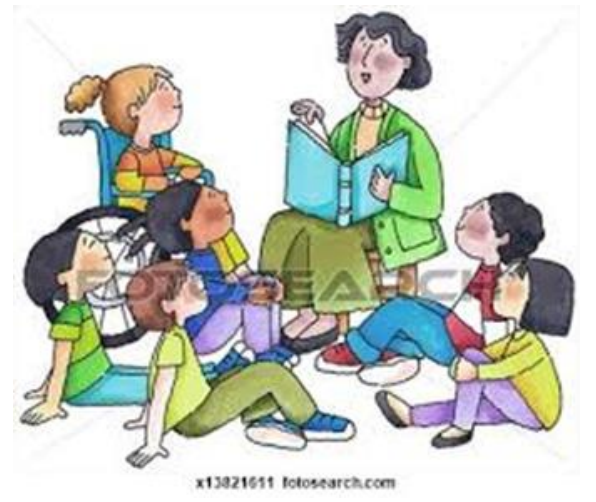

\section{Arculatteremtés}

\section{Az iskolaprofil kialakításának kérdései}

"Minden gondolatunk, minden tervünk azt célozza: hogy lehetne benneteket vidámabbá, életrevalóbbá, müveltebbé, derekabbá tenni."

/Karácsony Sándor/

\section{Bevezetö}

A 20. század első felének legismertebb, a legtöbbek által elfogadott és elismert tanítójának gondolata tanári pályám mottója. Igyekszem minden nap e gondolat szerint végezni a munkámat, és arra törekszem, hogy mindezt egy olyan intézményben tehessem, amelybe belépve is ezt a szemléletet szippantja be a gyermek, a szülö és a pedagógus egyaránt. Ez csak akkor valósulhat meg, ha a nevelésben-oktatásban részt vevő valamennyi szereplő ugyanazon célok felé tör: egységes szemléletben, összefogva, egymást partnernek tekintve és együtt dolgozva-gondolkodva hozza létre és müködteti a 21 . század sikeres intézményét, a jövő „,intelligens iskoláját"1.

2013-ban, a fenntartóváltásnak köszönhetően megnyílt az út egy olyan valós igényeken alapuló arculatteremtésre, amely számukra és diákjai szüleinek számára is valós igényeken alapul. Természetesen nem elég hangzatos frázisokkal megtüzdelt pedagógiai programot készíteni, az abban foglaltak megvalósításához hosszabb időre és kitartó, áldozatos munkára van szükség mind a vezetők, mind az iskolában dolgozó pedagógusok részéröl. Mindemellett nem feledkezhetünk meg a szülökről sem: őket bevonva, a velük folytatott folyamatos kommunikációval érhetünk csak el sikereket.

1. ábra

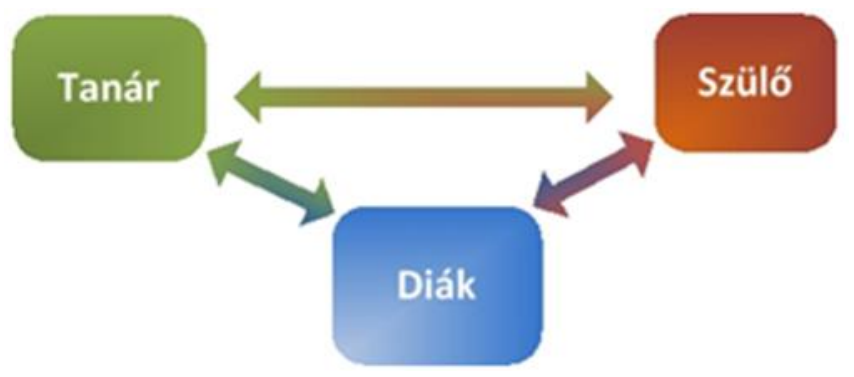

\footnotetext{
${ }^{1}$ Barbara MacGilchrist-Kate Myers-Jane Reed:A sikeres iskola. Az intelligensen működő szervezet. Müszaki Könyvkiadó Kft.,2011. Budapest
} 


\section{Az iskola és a marketing - ahol a cél a minél több gyermek}

Szabad az iskolaválasztás. A beiskolázási körzethatárok ugyan megvannak, de csak névlegesek. „Ma a legtöbb iskola azért küzd, hogy minél több gyereket „csalogasson” az intézménybe. Népszerü programokat ajánlanak, gazdag szabadidős lehetőségeket biztosítanak, vagy szerényebb hírveréssel erejükhöz mérten próbálnak olyasmit nyújtani, amelyre feltehetőleg igény lesz a jövőben."

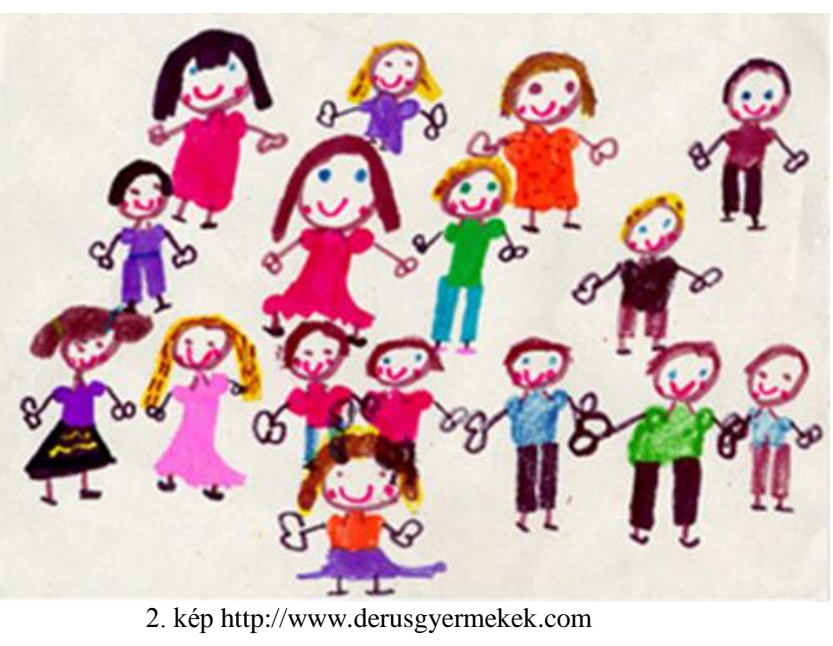

Mit kell ahhoz tenni, hogy az adott iskolát válasszák a szülők és a gyerekek valamint, hogy elégedettek is legyenek, ezért ott is maradjanak?

A szülők iskolaválasztási döntésében a leginkább mérlegelt szempontok: ${ }^{3} \quad 2$ ábra

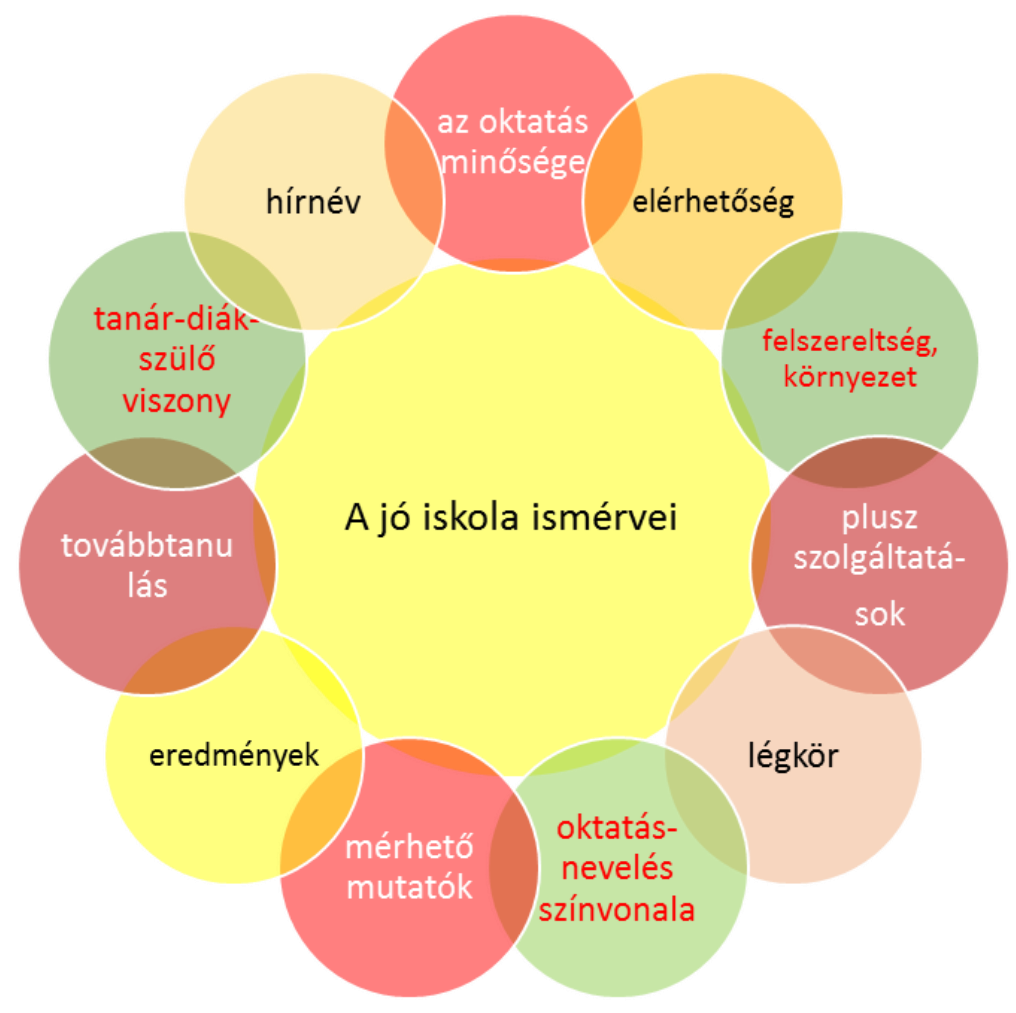

\footnotetext{
${ }^{2}$ Muhi B. Béla: Az iskolamarketing elméleti és gyakorlati kérdései http://www.nyeomszsz.org letöltési idő: 2015. március 7.

${ }^{3}$ Muhi B. Béla: Az iskolamarketing elméleti és gyakorlati kérdései http://www.nyeomszsz.org letöltési idő: 2015. március 7.
} 
Egy jól müködő iskola, egy menedzser szemléletű vezető nemcsak reagál a kor, a társadalom és a szülők megújuló igényeire, hanem megpróbál eléjük menni, megelőzni azokat. Mivel a köznevelésben lassabban kivitelezhetö bármilyen változtatás, mint a versenyszférában, ezért elörelátónak, elöre gondolkodónak, újszerünek és mindig nyitottnak kell maradni. Soha nem elégedhetünk meg a már elért eredményekkel, a bevált gyakorlattal, hiszen rövid- és középtávon talán jól müködik, de hosszú távon biztosan kell rajta változtatni, újítani. A köznevelésben is hosszú idő a 10-15 év. Ha nem számítjuk a törvényi változásokat, a politikai harcokat, csupán a környezetünkben lezajló változásokra figyelünk, ennyi eltelt idő alatt akkor is megszokottá, „hagyományossá”, általánossá válunk az addig jó iskolánkkal.

Egy rövid felsorolásnak elegendő intézményünknek megfelelni ahhoz, hogy úgy érezzük, a XXI. század köznevelési intézményében dolgozunk. A korszerü közoktatási intézmény ismérveit Benczéné Csorba Piroska tanulmánya ${ }^{4}$ alapján gyüjtöttem össze.

3. ábra

alternatív pedagógiai módszerek

modern eszközök, korszerű tanulási technika

játékos, kreatív tanulás

magújulás és szemléletváltás

vonzó tanterv

modern iskolamódszertan

diákcentrikusság, eredetiség

virtualitás, interaktív képzés

új pedagógiai és módszertani alapvetések

Célszerü megvizsgálni, hogy mennyire lehet megfelelni ezeknek a követelményeknek. Az elöbb felsorolt ismérvek között természetesen van, amelyik fenntartó- és pénzfüggő, így lehet arra hivatkozni, hogy - bár mi nagyon szeretnénk - sajnos nem kapjuk meg. Ilyenek a modern technikai eszközök. Rögtön felmerül a kérdés: A meglévőket vajon milyen mértékben és színvonalon használjuk ki? Az intézmény érékelésénél ez is egy fontos szempont.

A többi ismérv azonban nem pénz függvénye, hanem az intézmény dolgozóinak hozzáállásától, mentalitásától, elhivatottságától függ. Nagyon fontos tényező egy iskola müködésének vizsgálatakor az ott dolgozó pedagógusok átlag életkora. Ha túl fiatal, akkor bármennyire is tele van lelkesedéssel és új ismeretekkel, hiányzik a tapasztalat, az állandóság. Ha éppen az ellenkezője, azaz idősödő tantestületet nézünk, általánosságban már kevésbé fogékonyak az újra, nehezebben tartják a lépést a modern technikai fejlődéssel és már az igényük is kevesebb a megújulásra. Szerencsés az az intézményvezető, amely olyan tantestületet irányíthat, amelynek tagjai már kellő tapasztalattal rendelkeznek, de még nem a pályájuk végét várják, a

${ }^{4}$ Benczéné Csorba Piroska: A jövő iskolája www.berkisk.hu/dokumentumtar letöltési idö: 2015. március 10. 
méltán megérdemelt pihenést, éppen ezért még tettre készek, hajlandóak a folyamatos megújulásra, az önképzésre, akiknek fontos a biztos munkahely.

Ez utóbbi intézmény müködését tudja segíteni az iskolamarketing, hogy megteremtsék azt az intézményt, mely leginkább megfelelhet a XXI. századi új kihívásainak.

\section{Milyen is legyen a holnap iskolája ${ }^{5}$}

A XXI. század iskolájának olyan rugalmas struktúrával kell rendelkeznie, amely változatos tanulási lehetőséget kínál minden diákja számára., ezzel is ösztönzést nyújtva az élethosszig tartó tanulás (lifelong learning) igényének kialakulására. Ehhez elsősorban a kulcskompetenciákra kell helyeznie a hangsúlyt, azaz előtérbe kell, hogy lépjen a kompetencia alapú oktatás. A jó iskola a befogadást - elfogadást, együttnevelést természetesnek tekinti, esélyt teremt mindenki számára azzal, hogy alkalmazásképes tudást kínál oly módon, hogy tiszteletben tartja az egyéni különbségeket és azt vallja: minden gyermek tehetséges valamiben.

\section{A vállalati/intézményi arculat}

A corporate identity, azaz a vállalati/intézményi arculat fogalmát sokan és sokféle megközelítésből próbálták meghatározni. Számomra a legelfogadhatóbb és az oktatási intézményekre leginkább alkalmazható megközelítés a Melewar és Karaosmanoglu-féle arculati mix. ${ }^{6}$ A szerzők hét dimenzióba sorolják az arculatra ható tényezőket és ezek fogalmi bemutatásával írják le az arculat fogalmát.

Az arculati mix fö elemei: 4. ábra

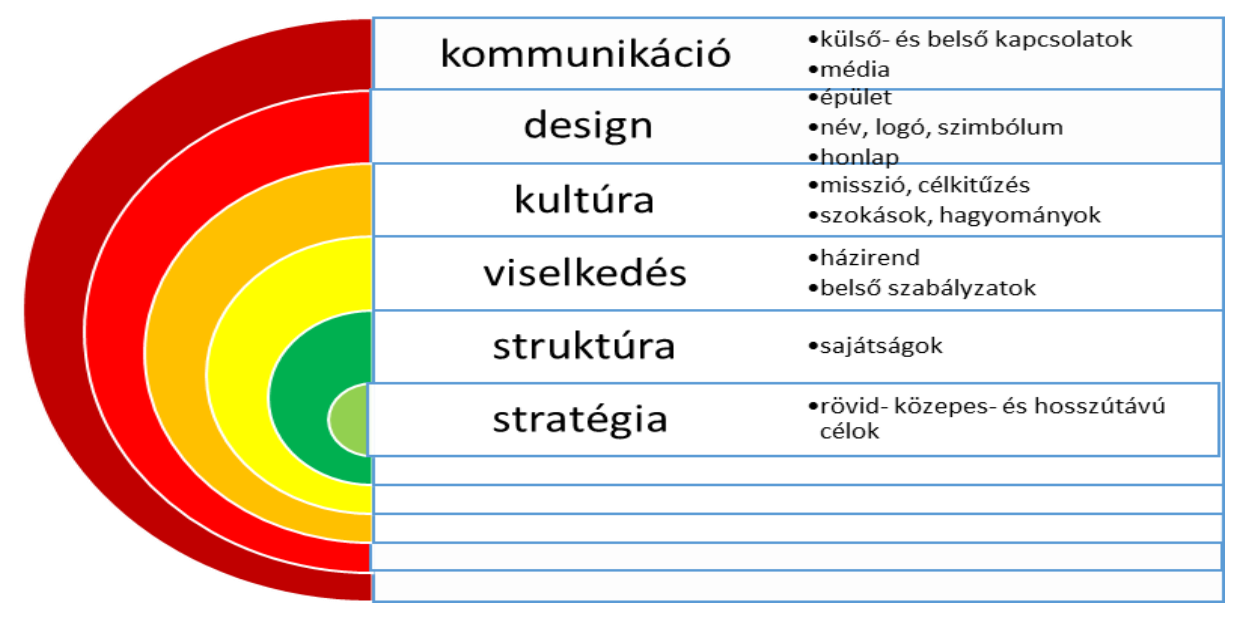

\section{Az új típusú vezetö}

Az iskolaarculat megteremtéséért és annak vonzóvá tételéért, a vonzás megtartásáért és a folyamatos megújulásért mindig az intézményvezető felel.

Olyan felelősség ez, amely nem vállalható bárkinek, hiszen sok ember munkája függ tőle. Ahhoz, hogy valaki elvállalja napjainkban egy köznevelési intézmény vezetését, nem egyszerüen jó pedagógusnak, pszichológusnak és az eddig megszokott értelembe vett

\footnotetext{
${ }^{5}$ Benczéné Csorba Piroska: A jövő iskolája www.berkisk.hu/dokumentumtar letöltési idö: 2015. március 10.

${ }^{6}$ Melewar, T. C. and Karaosmanoglu, E.: Seven dimensions of corporate identity. 2006, p 846-869.
} 
vezetőnek kell lennie, hanem menedzsernek, aki képes előre látni a változásokat, és felismerve öket képes gyorsan reagálni is rájuk.

Milyen is legyen a XXI. század iskolájának vezetője? Megpróbálom összefoglalni:

5. ábra

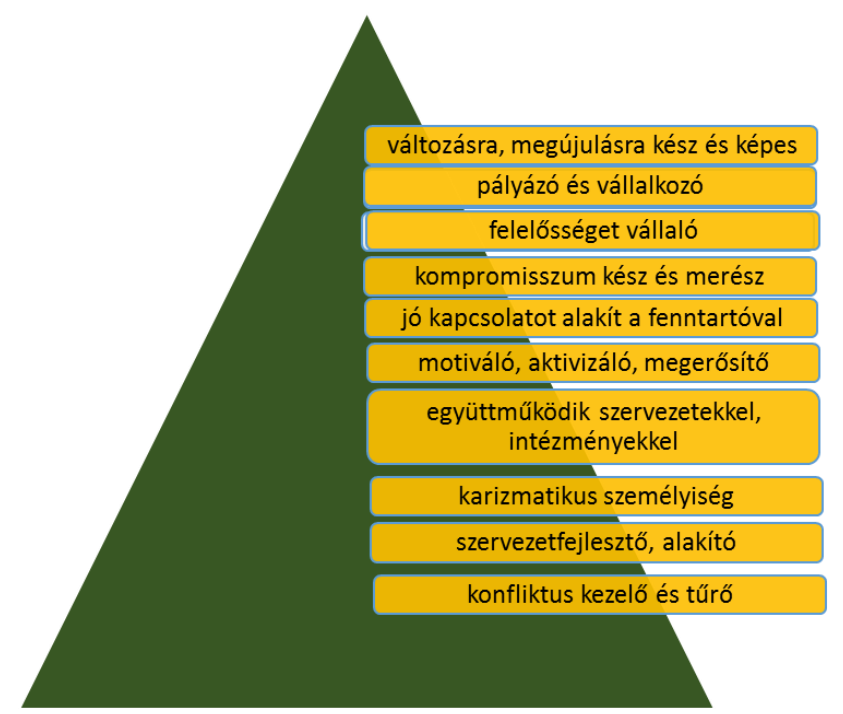

A felsorolással természetesen nem fontossági sorrendet szerettem volna állítani, hiszen mindegyik személyiségjegy egyszerre valósul meg az eszményi vezetőben. A valóságban úgy gondolom, igen ritka az az intézményvezetö, amelyben a felsoroltak közül valamennyi tulajdonság egyszerre megtalálható. De minél többel rendelkezik, annál jobban megvalósíthatja a saját modern iskoláját.

\section{Az iskolaarculat vizsgálatának módszerei}

Ahhoz, hogy megtudjuk, mennyire felel meg egy adott intézmény a XXI. század iskolájával szemben támasztott követelményeknek, meg kell vizsgálni az intézménnyel kapcsolatba kerülő valamennyi résztvevő véleményét. Az intézmény dolgozóinak, a diákoknak és a diákok szüleinek véleményét megismerve, elemezve és összevetve lehetőség nyílik a helyes, tovább folytatandó elképzelések megerősítésére, a feltárt új igények és lehetőségek megismerésére, de a vizsgálat szükséges ahhoz is, hogy rájöjjünk azokra a pontokra, ahol esetleg eltévedtünk, ami nem jól müködik.

A leghatékonyabb módszereknek az interjúkészítést, a SWOT analízist és a kérdőívezést tartom, e cikkben is ezekkel az eszközökkel, a mélyinterjúval és a SWOT analízissel igyekszem feltárni a vizsgált iskola jelenlegi helyzetét és a kapott eredmény alapján egy rövidtávú feladatterv kidolgozásával segíteni és megerősíteni az intézményt pozíciójának megtartásában, esetleg javításában. 
Példa az iskolaprofil vizsgálatára és egy rövidtávú fejlesztési terv kidolgozására

\section{A Hunyadi Mátyás Általános Iskola Vizafogó Tagiskolája}

3. kép

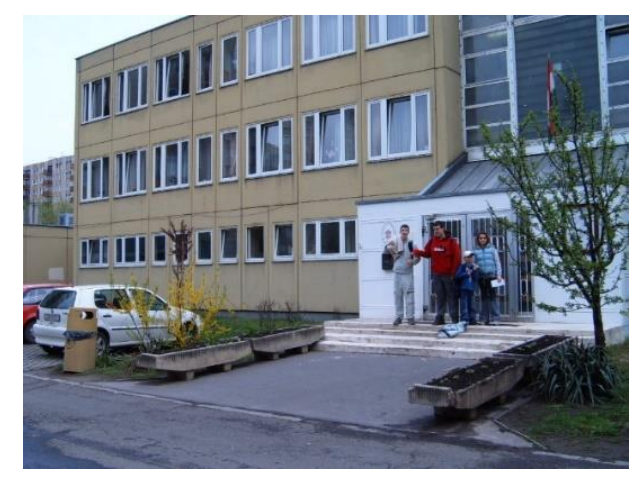

Az iskola 1983-ban nyitotta meg kapuit a főváros XIII. kerületének Vizafogó részén, lakótelepi környezetben. A megalakuláskor a Vizafogó Általános Iskola nevet kapta.

Bár emeletes házak veszik körül, mikrokörnyezete mégis család- és gyermekbarát: közelében található a Dunapart, a Margitsziget, számos park és játszótér. Az iskola 32 éve változatlan külleme nem sejteti, hogy a belépőket milyen meleg, családias légkör fogadja. A sárga és zöld színek, a ágas folyosó, a barátságosan berendezett, maximum 25 gyermek befogadására képes osztálytermek és az itt dolgozók őszinte s kedves mosolya köszönti az iskolába lépőket.

\section{Az iskola pedagógiai munkája}

\section{" Minőségi nevelési-oktatási intézmény". „ÖKO iskola” „A Pesti Magyar Színház bázisiskolája"}

2007-ben bekövetkezett integráció után a Hunyadi Mátyás Általános Iskola tagiskolájaként működik. Neve: Hunyadi Mátyás Általános Iskola Vizafogó Tagiskolája. A két iskolának 1 igazgatója van, az iskolában tagintézmény-vezető látja el a vezetői feladatokat, igazgatói irányítás mellett.

Mélyinterjú Szállási Zsuzsannával, a tagintézmény vezetőjével

1. kérdés: Milyen típusú intézményt vezet?

Válasz: Iskolánk 8 évfolyamos általános iskola.

2. kérdés: Milyen sajátosságai vannak az intézménynek a Pedagógiai Programja alapján? Válasz:

1990-től egyedi engedéllyel első osztálytól differenciáltan angol nyelvet tanítunk

2010-től mozgás- és táncművészeti osztály indítására került sor. 
A 2013-2014. tanévtől a "Nyitott világ" nevelési-oktatási program elnevezéssel a két tanítási nyelvi irányultságú osztályt indítunk.

Magas szintü informatika oktatást biztosítunk.

3. kérdés: Milyenek a tárgyi és személyi feltételek?

Válasz:

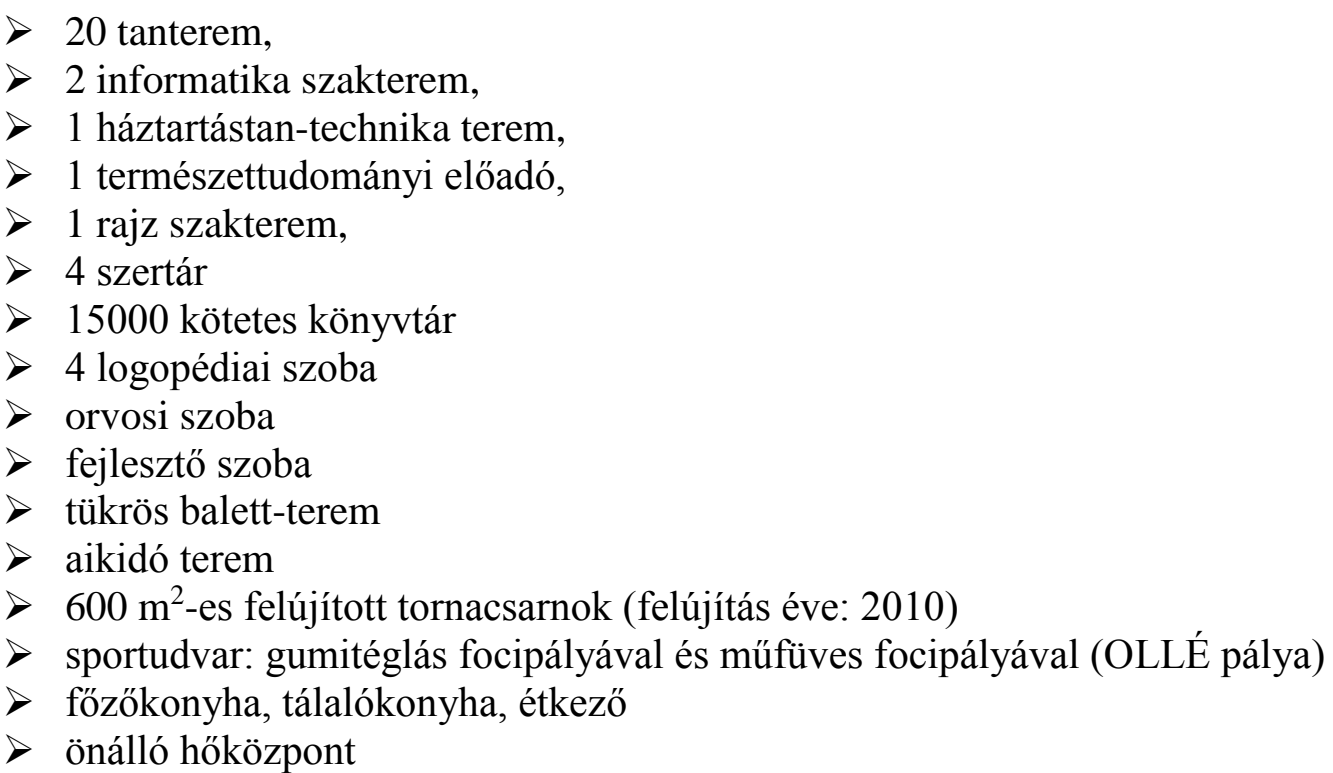

Tantermeink és szertáraink felszereltsége jónak mondható, 6 tanteremben interaktív tábla segíti munkánkat.

Személyi feltételek: 27 tanító és tanár dolgozik iskolánkban, 1 föállású könyvtáros, 1 pedagógiai asszisztens, 1 iskolatitkár, 0,5 informatikus, 4 utazó gyógypedagógus 1 fejlesztő pedagógus segíti a mindennapos oktató nevelő munkát. Pedagógiai programunk megvalósításában közremüködik még 1 néptánc szakoktató, néptáncmüvész, 1 balett-tanár, balettművész, 1 sporttánc oktató, 1 aikidó edző, aikidó mester.

Átlagos életkor tekintetében középkorúnak mondható a tantestület, ezért pedagógiai tapasztalat, élettapasztalat, nagy munkabírás jellemzi őket.

Kollégáim szakmai felkészültsége nagyon jó, innovatív gondolkodás, az új iránti nyitottság, értéktartó magatartás, magas szintü tárgyi tudás jellemzi őket. A tanórákat szakos kollégák tartják. A pedagógiai program megvalósításában mindenki elkötelezetten vesz részt.

4. kérdés: Honnan érkeznek az intézménybe a beiratkozó gyermekek?

Válasz: Tanulóink szinte teljesen a XIII. kerületből, nagyrészt körzetünkből kerülnek ki.

5. kérdés: Milyen külső kapcsolatai vannak az intézménynek?

Válasz: Külső kapcsolataink kiválóak, együttműködési megállapodásunk van a Pesti Magyar Színházzal, és több óvodával. Jó kapcsolatot ápolunk a többi iskolával, szakszolgálatokkal, pl. Prizma EGYMI, 3. számú TANAK, Beszédvizsgáló Országos Szakértői és Rehabilitációs Bizottság, kerületi közművelődési intézmények: könyvtár, RAM, József Attila Művelődési Központ, Dagály Gyerekház. 


\section{Az iskola profiljai}

\section{A mozgás- és táncmüvészeti osztály ${ }^{7}$}

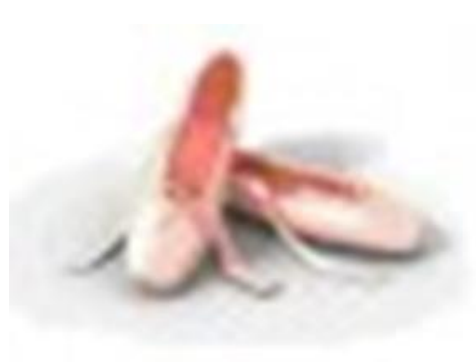

egyik fö célként.

A Vizafogó Tagiskolában talán a fővárosunkban is elsőként indult be a speciális mozgás- és táncmüvészeti osztály, amelyben a legkülönbözőbb mozgásformák elsajátíttatása révén igyekeznek a gyermekek személyiségét, ügyességét, állóképességét fejleszteni, miközben az egészséges életre nevelés egyik legfontosabb területén is fontos feladatot látnak el.

Speciális mozgás,- és táncmüvészeti osztályuk programjában a legkülönbözőbb mozgásformák "egyidejü" oktatását tüzték ki

A mozgásformák elsajátítása során a tanulók megismerkedhetnek népi mozgáskultúránk alapjaival, a néptánccal, a népi játékokkal, népdalokkal. Az aikido oktatása nagyban segíti a gyermekek állóképességének fejlesztését, miközben az egészség megőrzésén túl, a belső világ felé fordulás jelentőségét is megismerhetik. Az iskolában komoly múltra tekint vissza a sporttánc oktatás, melynek során a gyermekek ügyessége, ritmusérzéke, térérzékelése fejlődik. A balett oktatás nélkülözhetetlen része a mozgásművészeti nevelésnek, hangsúlyt adva a mozgás érzelmeket, gondolatokat kifejező művészi erejének.

A mozgás,- és táncmüvészeti osztályokban, speciális képzésüknek megfelelően, speciális szakemberek dolgoznak. A balettet balettmüvész, az aikidót aikido mester, a néptáncot, néptánctanár, a sporttáncot szakedző tanítja.

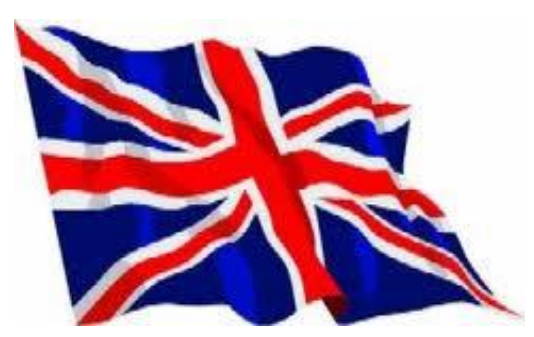

\section{A "Nyitott világ"8}

A két tanítási nyelvi irányultságú osztályokban, a helyi tantervükben már első osztályban bevezetésre kerülő délelötti angoloktatást követően a délutáni időszakban is folytatódik hetente három alkalommal az angol nyelv oktatása, különböző tantárgyi területen történő alkalmazása, amely a két tanítási nyelv oktatásának feltétele és alapja.

A gyermekek a délutáni angol órákon belül az angol anyanyelvi országokhoz kapcsolódó ismeretekkel, kulturális hagyományokkal, infokommunikációs ismeretekkel, természetismeret angol nyelvü oktatásával is foglalkoznak szakemberek vezetésével.

\section{SWOT analízis}

A tagintézmény-vezető asszonnyal folytatott beszélgetés után a nevelőtestületet kérdeztem saját intézményük müködésével kapcsolatos véleményükről SWOT analízis formájában. Az analízisre novemberben került sor egy tantestületi értekezlet alkalmával.

A mérés összegzése:

\footnotetext{
${ }^{7}$ http://www.vizafogo.bp13.hu/ letöltési idő: 2015.02.21.

${ }^{8}$ http://www.vizafogo.bp13.hu/ letöltési idő: 2015.02.21.
} 
Az analízisben résztvevők száma: 29 fö. 27 pedagógus, 1 könyvtáros-tanító, 1 fejlesztő pedagógus.

Ürlapot kitöltők száma: 29 fö.

Kitöltési arány: $100 \%$

A kiértékelt lapok alapján megállapítható, hogy a Vizafogó Tagiskola nevelőtestülete alaposan ismeri saját intézményét, reálisan értékelik iskolájukat.

A válaszok összegzése: 1. számú melléklet

\section{Az iskola arculatának feltárt elemei}

$\mathrm{Az}$ arculat kialakítása elsősorban az iskolavezetés és a tantestület feladata. A vezetői mélyinterjú és a SWOT analízis eredményének tükrében a következőkben szeretném bemutatni, milyennek találtam az iskolaarculatot az elméleti részben bemutatott modell alapján.

\section{Intézményi kommunikáció}

A Vizafogó Tagiskola $P R$ tevékenysége az elmúlt években egyre intenzívebbé vált. Gyakran jelent meg a kerületi újságban cikk az iskola jelentősebb eseményeiről, szerepeltek a kerületi és az országos televízióban. Az intézmény képviseltette magát a kerületi rendezvényeken.

Az iskolai menedzsment nagyon fontosnak tartja a külső partnerekkel, érintettekkel történő kommunikációt. Igyekszik megfelelő kapcsolatrendszert kialakítani.

A belső kommunikáció a havi és alkalmi megbeszélések, tájékoztatások alkalmával valósul meg illetve a vezetőség és a beosztottak személyes jó kapcsolata is elősegíti a hatékony kommunikációt. Az iskola vezetői és a pedagógusok egyaránt úgy látják, hogy a belső kommunikáció hatékonyságát azért még lehet és kell is fejleszteni.

\section{Intézményi design}

A különböző rendezvényeken történő egységes megjelenés, „intézményi design” érdekében vizás emblémával ellátott pólót készíttetett az intézmény.

A hivatalos levelezéshez, nyomtatott tájékoztatáshoz egységes fejléccel és logóval ellátott papírt használnak.

\section{Szervezeti kultúra}

Az intézmény rendelkezik hosszabb távú célkitüzésekkel, melyekre a reális, de pozitív gondolkodás jellemző. Az iskola kettős célja: a hátrányos helyzetü tanulók esélyegyenlőségének megteremtése és a tehetségek kibontakoztatása. E kettős célt szolgálják az intézményi Pedagógiai Program egyedi vonásai.

\section{Az intézményi magatartás, viselkedés}

Az intézmény számos, immár hagyományosnak mondható rendezvényével lehetővé teszi a mindennapi életébe való bepillantást az érdeklődők számára. A szülők, hozzátartozók, leendő diákjaik szülei és az érdeklődők számára is nyitott programjaik: Halacskaavató, Meseszombat, Viza Családi Szombat, Hunyadi-Viza Gála (a törzsiskolával közösen megrendezett müvészeti bemutató).

\section{Az intézményi struktúra}


Az intézményben 27 pedagógus dolgozik, ebből ketten alkotják az iskola vezetését. A három munkaközösség-vezető felügyeli az egyes tantárgyak tanítóit, szakmai segítséget nyújtanak nekik. Az arculat szempontjából tehát nem meghatározó a struktúra, hiszen szinte minden iskola ugyanilyen felépítéssel rendelkezik, csak a számok térnek el, de a hierarchia nem. A hatékonyság, a szolgáltatás minősége inkább meghatározóak, melyek a szervezeti struktúrával szoros kapcsolatban állnak.

\section{Az intézményi stratégia}

Az iskola a profiljának megfelelően és a hitvallásával megegyezően a tehetséggondozásra és az esélyegyenlőség megteremtésére helyezi a hangsúlyt közép és hosszú távú stratégiájának megfogalmazásakor, mely teljes mértékben megfelel a közoktatás aktuális elvárásainak.

\section{A Vizafogó Tagiskola arculatteremtő munkájának középtávú terve}

Az iskolában folytatott felmérés végső fázisaként egy olyan cselekvési tervet dolgoztam ki a tantestülettel közösen, melynek megvalósítását a teljes tantestület elfogadta. Mivel a terv konkrét résztvevőket, időpontokat és felelősöket nevez meg, cikkemben csak a tevékenységet, az elvárt eredményt és a felelős beosztását szeretném ismertetni.

\section{Cselekvési terv: 2. számú melléklet}

\section{Záró gondolatok}

Az iskola arculata valójában az intézmény valamennyi dolgozójának, diákjának, a gyerekek szüleinek a tükre. Hiszen ha nem tudnánk azonosulni vele, valószínűleg másik munkahelyet kellene keresnünk. Amikor egy pedagógus állást keres, először megnézi kiválasztott intézmény profilját, tájékozódik az ott folyó munkáról az iskola honlapján, azaz megismeri annak arculatát. Majd dönt, hogy képes-e mindezzel azonosulni, a feladatokba bekapcsolódni. Ha igen, jelentkezik az állásra. De ugyanígy tesznek a gyermekük számára iskolát kereső diákok szülei is. Keresgélnek, információkat gyüjtenek, tájékozódnak a kiszemelt iskolákról, majd az elképzelésüknek leginkább megfelelő arculatú intézménybe beíratják gyermeküket. És éppen őmiattuk fontos maga az iskolamarketing, hiszen az az intézmény nyer, amelyik jobban el tudja magát adni, vagyis megfelelő menedzsmentje van.

\section{Felhasznált irodalomjegyzék}

- A sikeres iskola. Barbara MacGilchrist-Kate Myers-Jane Reed:. Az intelligensen müködő szervezet. Müszaki Könyvkiadó Kft.,2011. Budapest

- 2011. évi CXC. törvény a nemzeti köznevelésről 72.§(2.) http://net.jogtar.hu letöltés: 2014. október 30.

- 2011. évi CXC. törvény a nemzeti köznevelésről 45.§(2.) http://net.jogtar.hu letöltés: 2014. október 30 .

- Nagy László válogatott pedagógiai múvei. Tankönyvkiadó, Budapest, 1972. 342. o. 
- Rendszerváltás az iskolákban. Liskó Ilona http://oitk.tatk.elte.hu letöltés ideje: 2015. március 7.

- Az iskolamarketing elméleti és gyakorlati kérdései. Muhi B. Béla: http://www.nyeomszsz.org letöltési idő: 2015. március 7.

- A jövő iskolája. Benczéné Csorba Piroska www.berkisk.hu/dokumentumtar letöltési idö: 2015. március 10.

- Seven dimensions of corporate identity. Melewar, T. C. and Karaosmanoglu, E.: 2006, p 846-869.

- Intézményi arculat és identitás elemzése a Bercsényi Miklós Gimnázium és Kollégium példáján keresztül. Horváth Marianna - Tóth Tibor http://www.tanitani.info/084horvath letöltés dátuma: 2015. március 7.

- Milyen a motiváló iskola épülete?; Brezdom Iván Köznevelés 67. évfolyam 33-34. szám, 2011. október 28.

- Az iskolatervezés: jövőtervezés; Réti Mónika, Lippai Edit Új Köznevelés 69. évfolyam 6-7. 2013 augusztus-szeptember

- http://www.vizafogo.bp13.hu/ letöltési idő: 2015.02.21.

- A sikeres Iskola. Az intelligensen müködő szervezet. Barbara MacGilchrist-Kate Myers-Jane Reed; Müszaki Könyvkiadó Kft. Budapest, 2011.

- Eredményes iskola. Adatok és esetek. Lannert Judit-Nagy Mária; Országos Közoktatási Intézet. Budapest, 2006.

- Az intézményvezetés négy tétele. Benedek István; OKKER Oktatási Kereskedelmi és Szervezési Iroda. Budapest, 1999.

- A pedagógiai innováció menedzselése: vezetőknek és beosztottaknak: szervezetfejlesztési kézikönyv. szerk. Arthur W. Chickering; (magy. szerk. Horváth Attila); IF Alapítvány: BAZ megyei Pedagógiai és Közművelődési Intézet. Miskolc, 1992.

- Inkluzív nevelés - intézményfejlesztés és programadaptáció: kézikönyv a pedagógusképző intézmények számára. Hegyiné Honyek Katalin; Sulinova Kht. Budapest, 2006.

- Iskolamarketing a beiskolázás szolgálatában. Szabóné Szél Julianna; In: Kihívások és válaszok az általános iskolában. Szontagh Pál; Pont: Ikerhold. Budapest, 2004.

- Iskolamarketing a gyakorlatban: Mit tehetünk a tanulólétszám megtartásáért, növeléséért? Szabóné Szél Julianna; In: Iskolakultúra: Természettudomány társadalomtudomány 11. évf. 6-7.2011.

- Az iskola fejlődése és fejlesztése az Európai Unióban - lehetséges utak és tévutak. Bábosik István; In: A nevelés mint érték. Szerk. Karikó Sándor; Áron: Bozsek K. Budapest, 2010.

- Válaszol az iskola. Szerk. Simon Mária; OKI Budapest, 2004.

- Pedagógusok vagy iskolamenedzserek?: Vezetői szerepértelmezések tükröződése az igazgatók továbbképzésében és jövőképében. OKKER Oktatási, Kiadói és Kereskedelmi Kft. Budapest, 1998. 
- Az iskola szervezeti és vezetői jellemzői. Baráth Tibor; Új Pedagógiai Szemle 57. évf. 11. sz. 2007. p. 3-16.

- Az iskolavezetés jellemzői és az intézmény eredményessége, hatékonysága. Baráth Tibor; Új Pedagógiai Szemle 56. évf. 7-8. sz. 2006. p. 56-72.

- Milyen a jó igazgató? Novák Gábor; Köznevelés 67. évf. 38-39. sz. 2011. p. 5.

- A vezetői kompetenciák szerepe a XXI. századi iskolában. Novák Gábor; Köznevelés 67. évf. 38-39. sz. 2011. p. 6-8.

- Az iskolavezetés árnyoldalai. Novák Gábor; Köznevelés 67. évf. 38-39. sz. 2011. p. 8.

- Miért fontos, hogy az iskola szép legyen? Bezdom Iván; Köznevelés 67. évf. 33-34. sz.2011. p. 14-21.

- Alternatív oktatás; Köznevelés 68. évf. 40. sz. 2012. p. 7-8.

- Milyen a jó iskola? „Az európai út: az önfejlesztés”; Köznevelés 68. évf. 8-9. sz. 2012. p. 34-35. 


\section{1. számú melléklet}

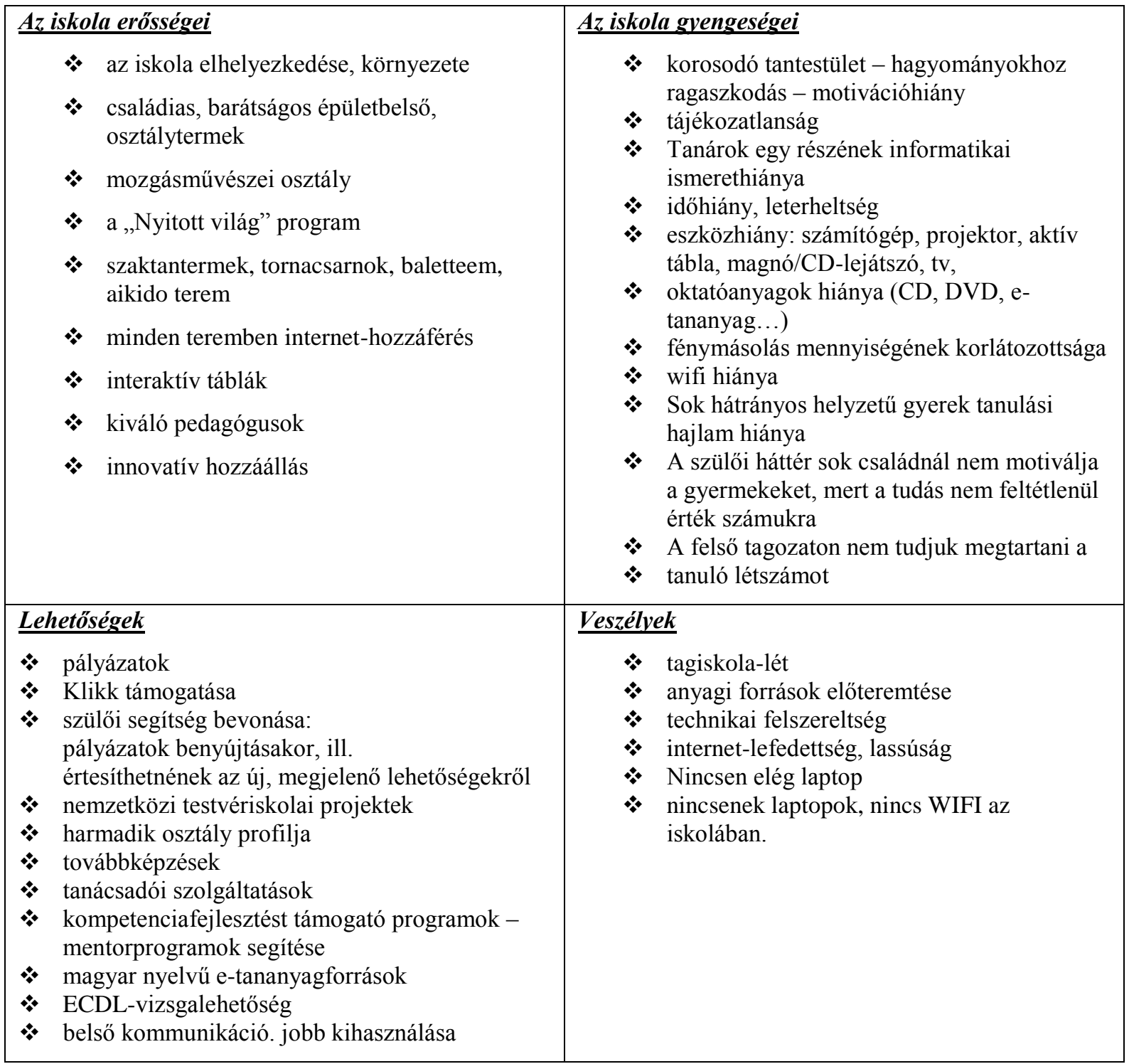


2. számú melléklet

\begin{tabular}{|c|c|c|c|c|c|}
\hline \multirow{3}{*}{ 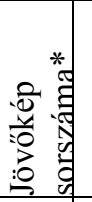 } & \multirow{3}{*}{$\begin{array}{c}\text { Tevékenység/projekt } \\
\text { leírása }\end{array}$} & \multirow[t]{3}{*}{ Elvárt eredmény } & \multicolumn{3}{|c|}{ Megvalósítása } \\
\hline & & & \multirow{2}{*}{ Felelös } & \multicolumn{2}{|c|}{ Megvalósítás ideje (év, hónap) } \\
\hline & & & & Kezdete & Vége \\
\hline & $\begin{array}{l}\text { PROJEKT: A XXI. } \\
\text { század iskolája } \\
\text { Az iskola arculatának, } \\
\text { értékeinek erösitése }\end{array}$ & $\begin{array}{c}\text { Az iskola } \\
\text { arculatának, } \\
\text { ismertségének és } \\
\text { elismertségének } \\
\text { növekedése }\end{array}$ & $\begin{array}{l}\text { tagintéz- } \\
\text { mény- } \\
\text { vezető }\end{array}$ & $\begin{array}{l}2015 . \\
\text { novem } \\
\text { ber } 1 .\end{array}$ & $\begin{array}{l}\text { 2017. decem } \\
\text { ber } 31 .\end{array}$ \\
\hline & Célcsoport kijelölése & & & & \\
\hline ت & $\begin{array}{l}\text { Iskolánk jelenlegi és } \\
\text { leendö tanulóinak szülei }\end{array}$ & $\begin{array}{l}\text { Programjainkon nagy } \\
\text { számú szülői } \\
\text { részvétel. }\end{array}$ & $\begin{array}{l}\text { tagintéz- } \\
\text { mény- } \\
\text { vezető, } \\
\text { osztályfö- } \\
\text { nökök }\end{array}$ & $\begin{array}{c}2015 . \\
\text { december } \\
1 .\end{array}$ & $\begin{array}{l}\text { 2017. december } \\
31 \text {. }\end{array}$ \\
\hline ִָ & Iskolánk diákjai & $\begin{array}{c}\text { Az iskola profiljainak } \\
\text { mind szélesebb körü } \\
\text { bemutatása }\end{array}$ & $\begin{array}{l}\text { tagintéz- } \\
\text { mény- } \\
\text { vezetö, } \\
\text { projektveze- } \\
\text { tő }\end{array}$ & $\begin{array}{c}2015 . \\
\text { december } \\
1 .\end{array}$ & $\begin{array}{l}\text { 2017. december } \\
31 \text {. }\end{array}$ \\
\hline$\doteq$ & $\begin{array}{l}\text { A jelenlegi helyzet } \\
\text { feltárása }\end{array}$ & & & & \\
\hline 戸 & $\begin{array}{c}\text { Az iskola éves } \\
\text { munkatervének } \\
\text { célirányos vizsgálata, a } \\
\text { lehetöségek keresése }\end{array}$ & $\begin{array}{c}\text { A munkatervben } \\
\text { szereplő programok } \\
\text { közül a célunknak } \\
\text { megfelelő események } \\
\text { kiemelése }\end{array}$ & $\begin{array}{c}\text { projektvezet } \\
\text { ô }\end{array}$ & $\begin{array}{c}2015 . \\
\text { november } \\
10 .\end{array}$ & $\begin{array}{l}\text { 2015. november } \\
14 .\end{array}$ \\
\hline ִֻ & SWOT analízis & $\begin{array}{l}\text { Erősségeink, } \\
\text { gyengeségeink, } \\
\text { lehetőségeink és } \\
\text { korlátaink } \\
\text { összegyüjtése }\end{array}$ & $\begin{array}{c}\text { projektvezet } \\
\text { ó }\end{array}$ & $\begin{array}{c}2015 . \\
\text { november } \\
14 .\end{array}$ & $\begin{array}{l}\text { 2015. november } \\
14 .\end{array}$ \\
\hline$\dot{\Xi}$ & Feladatkijelölés & & & & \\
\hline 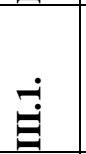 & $\begin{array}{c}\text { Mozgás- és } \\
\text { táncmüvészeti program }\end{array}$ & $\begin{array}{l}\text { A program mind } \\
\text { szélesebb körü } \\
\text { bemutatása }\end{array}$ & $\begin{array}{l}\text { projektvezet } \\
\text { ő, müvészeti } \\
\text { vezető }\end{array}$ & $\begin{array}{c}2015 . \\
\text { december } \\
1 .\end{array}$ & $\begin{array}{l}\text { 2017. december } \\
31 \text {. }\end{array}$ \\
\hline 巨 & $\underline{\text { Külsö kapcsolatok }}$ & & & & \\
\hline $\begin{array}{l}\rightleftarrows \\
\rightleftharpoons \\
戸\end{array}$ & $\begin{array}{c}\text { Külsö fellépési } \\
\text { lehetöségek keresése }\end{array}$ & $\begin{array}{l}\text { Félévente legalább } \\
\text { egy múvészeti } \\
\text { bemutató iskolán } \\
\text { kívül }\end{array}$ & $\begin{array}{l}\text { projektvezet } \\
\text { ô,müvészeti } \\
\text { vezető }\end{array}$ & $\begin{array}{c}2016 . \\
\text { január } \\
1 .\end{array}$ & $\begin{array}{l}\text { 2017. december } \\
31 \text {. }\end{array}$ \\
\hline 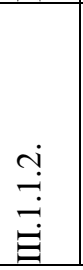 & $\begin{array}{c}\text { A Magyar Színházzal } \\
\text { fenntartott kapcsolatunk } \\
\text { további erösitése }\end{array}$ & $\begin{array}{c}\text { Színházbérlettel } \\
\text { rendelkező } \\
\text { osztályaink számának } \\
\text { növekedése }\end{array}$ & $\begin{array}{c}\text { projektvezet } \\
\text { ô }\end{array}$ & $\begin{array}{c}2016 . \\
\text { szeptember } \\
1 .\end{array}$ & $\begin{array}{l}\text { 2017. október } \\
31 .\end{array}$ \\
\hline
\end{tabular}




\begin{tabular}{|c|c|c|c|c|c|}
\hline 官 & $\begin{array}{c}\text { Drámapedagógiai } \\
\text { foglalkozások tartása a } \\
\text { színházi élményekhez } \\
\text { kapcsolódóan }\end{array}$ & $\begin{array}{l}\text { A színházbérlettel } \\
\text { rendelkező osztályok } \\
\text { bekapcsolódása a } \\
\text { színházi } \\
\text { drámapedagógiai } \\
\text { programba }\end{array}$ & $\begin{array}{c}\text { projektvezet } \\
\text { on }\end{array}$ & $\begin{array}{c}2016 . \\
\text { szeptember } \\
1 .\end{array}$ & $\begin{array}{l}\text { 2017. december } \\
31 .\end{array}$ \\
\hline 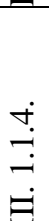 & $\begin{array}{l}\text { Részvétel a József Attila } \\
\text { Szinház felhívásán }\end{array}$ & $\begin{array}{c}\text { Az iskolai színjátszó } \\
\text { csoport szereplése a } \\
\text { színház Ádámok és } \\
\text { Évák címủ } \\
\text { projektjében }\end{array}$ & $\begin{array}{c}\text { projektvezet } \\
\text { ö }\end{array}$ & $\begin{array}{c}2015 . \\
\text { november } \\
5 .\end{array}$ & 2017. március 27. \\
\hline 官 & $\begin{array}{c}\text { Kapcsolatfelvétel az } \\
\text { óvodákkal }\end{array}$ & $\begin{array}{l}\text { A környezö óvodák } \\
\text { óvoda- } \\
\text { pedagógusainak } \\
\text { megismertetése } \\
\text { múvészeti } \\
\text { programunkkal }\end{array}$ & $\begin{array}{l}\text { tagintéz- } \\
\text { mény- } \\
\text { vezetö, } \\
\text { müvészeti } \\
\text { vezető }\end{array}$ & $\begin{array}{l}2016 . \\
\text { március } \\
16 .\end{array}$ & $\begin{array}{l}\text { 2017. március } \\
20 .\end{array}$ \\
\hline 范 & Belsö fellépések & & & & \\
\hline 穴 & $\begin{array}{c}\text { A müvészeti programunk } \\
\text { eredményességének } \\
\text { bemutatása } \\
\text { Hagyományos } \\
\text { rendezvényeinkre a } \\
\text { szülők és az óvodás } \\
\text { szülők mellett a média } \\
\text { meghívása }\end{array}$ & $\begin{array}{c}\text { Több alkalommal } \\
\text { megjelenés a kerületi } \\
\text { médiában }\end{array}$ & $\begin{array}{l}\text { intézmény- } \\
\text { vezető, } \\
\text { tagintéz- } \\
\text { mény- } \\
\text { vezető }\end{array}$ & $\begin{array}{c}2015 . \\
\text { december } \\
1 .\end{array}$ & $\begin{array}{l}\text { 2017. december } \\
31 .\end{array}$ \\
\hline 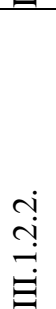 & $\begin{array}{l}\text { Nyilt müvészeti hét } \\
\text { rendezése }\end{array}$ & $\begin{array}{c}\text { A művészeti } \\
\text { foglalkozások } \\
\text { bemutatása az } \\
\text { óvodásoknak és } \\
\text { szüleiknek, valamint } \\
\text { a saját diákjainknak } \\
\text { és szüleiknek }\end{array}$ & $\begin{array}{l}\text { müvészeti } \\
\text { vezető }\end{array}$ & $\begin{array}{c}2016 . \\
\text { február } \\
1 .\end{array}$ & $\begin{array}{l}\text { 2017. február } \\
28 .\end{array}$ \\
\hline 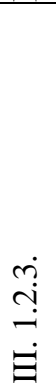 & $\begin{array}{l}\text { Kapcsolatépités más } \\
\text { müvészeti ágakkal }\end{array}$ & $\begin{array}{l}\text { Az iskolában müködö } \\
\text { képzőmüvészeti } \\
\text { szakkörök, } \\
\text { foglalkozások } \\
\text { munkáiból kiállítás } \\
\text { szervezése, } \\
\text { mozgásművészeti } \\
\text { bemutatóval } \\
\text { összekötve }\end{array}$ & $\begin{array}{c}\text { projektvezet } \\
\text { ő }\end{array}$ & $\begin{array}{l}2016 . \\
\text { április } \\
1 .\end{array}$ & $\begin{array}{l}\text { 2016. április } \\
30 .\end{array}$ \\
\hline 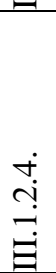 & $\begin{array}{c}\text { Kapcsolatunk szélesitése } \\
\text { a kerületi zeneiskolával }\end{array}$ & $\begin{array}{l}\text { A zeneiskolás } \\
\text { növendékeink } \\
\text { számának } \\
\text { növekedése, } \\
\text { fellépésük } \\
\text { rendezvényeinken }\end{array}$ & $\begin{array}{l}\text { projektvezet } \\
\text { ő,művészeti } \\
\text { vezető }\end{array}$ & $\begin{array}{c}2016 . \\
\text { január } \\
1 .\end{array}$ & $\begin{array}{l}\text { 2017. december } \\
31 .\end{array}$ \\
\hline 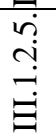 & $\begin{array}{l}\text { Müvészeti tábor } \\
\text { szervezése }\end{array}$ & $\begin{array}{l}\text { Nyári múvészeti } \\
\text { tábor szervezése }\end{array}$ & $\begin{array}{c}\text { projektvezet } \\
\text { ö }\end{array}$ & $\begin{array}{l}2016 . \\
\text { július }\end{array}$ & 2016. július \\
\hline
\end{tabular}




\begin{tabular}{|c|c|c|c|c|c|}
\hline 兽 & $\begin{array}{c}\text { "Nyitott világ" angol két } \\
\text { tanítási nyelvi } \\
\text { irányultságú program }\end{array}$ & $\begin{array}{c}\text { Az új program } \\
\text { eredményessé-gének } \\
\text { bemutatása }\end{array}$ & $\begin{array}{l}\text { projektvezet } \\
\text { "̈, "Nyitott } \\
\text { világ" } \\
\text { vezető }\end{array}$ & $\begin{array}{c}2016 . \\
\text { január } \\
1 .\end{array}$ & $\begin{array}{l}\text { 2017. december } \\
31 .\end{array}$ \\
\hline 亡َ & Belsö lehetöségek & & & & \\
\hline 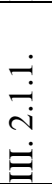 & Iskolai verseny & $\begin{array}{l}\text { Iskolai angol nyelvü } \\
\text { vers- és mesemondó } \\
\text { verseny szervezése }\end{array}$ & $\begin{array}{l}\text { projektvezet } \\
\text { ",, "Nyitott } \\
\text { világ" } \\
\text { vezető }\end{array}$ & $\begin{array}{l}2016 . \\
\text { április } \\
15 .\end{array}$ & $\begin{array}{l}\text { 2017. április } \\
15 .\end{array}$ \\
\hline 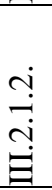 & $\begin{array}{l}\text { Fellépés az iskolai } \\
\text { rendezvényeken }\end{array}$ & $\begin{array}{l}\text { Hagyományos iskolai } \\
\text { rendezvényein-ken } \\
\text { angol nyelvü } \\
\text { bemutatók tartása }\end{array}$ & $\begin{array}{l}\text { projektvezet } \\
\text { ö, "Nyitott } \\
\text { világ" } \\
\text { vezető }\end{array}$ & $\begin{array}{c}2016 . \\
\text { január } \\
1 .\end{array}$ & $\begin{array}{l}\text { 2017. december } \\
31 \text {. }\end{array}$ \\
\hline 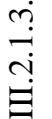 & Angol tábor szervezése & $\begin{array}{l}\text { Nyári angol tábor } \\
\text { szervezése }\end{array}$ & $\begin{array}{c}\text { projektvezet } \\
\text { ő }\end{array}$ & $\begin{array}{c}2016 . \\
\text { augusztus }\end{array}$ & 2017. augusztus \\
\hline 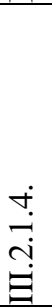 & "Nyitott világ" nyillt hét & $\begin{array}{l}\text { A "Nyitott világ" } \\
\text { foglalkozásainak } \\
\text { bemutatása az } \\
\text { óvodásoknak és } \\
\text { szüleiknek, valamint } \\
\text { a saját diákjainknak } \\
\text { és szüleiknek }\end{array}$ & $\begin{array}{l}\text { projektvezet } \\
\text { o,, "Nyitott } \\
\text { világ" } \\
\text { vezető }\end{array}$ & $\begin{array}{l}2016 . \\
\text { március } \\
13 .\end{array}$ & $\begin{array}{l}\text { 2016. március } \\
17 .\end{array}$ \\
\hline ָัن & Külsö lehetöségek & & & & \\
\hline 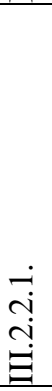 & $\begin{array}{l}\text { Kapcsolat a British } \\
\text { Council-lal }\end{array}$ & $\begin{array}{l}\text { Együttmüködés } \\
\text { kezdeményezése a } \\
\text { British Council } \\
\text { képviselőjével }\end{array}$ & $\begin{array}{l}\text { intézményv } \\
\text { ezető, } \\
\text { tagintéz- } \\
\text { mény- } \\
\text { vezető, } \\
\text { projektvezet } \\
\text { ő, "Nyitott } \\
\text { világ" } \\
\text { vezető }\end{array}$ & $\begin{array}{c}2016 . \\
\text { január } \\
1 .\end{array}$ & $\begin{array}{l}\text { 2016. január } \\
\text { 31. }\end{array}$ \\
\hline 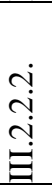 & $\begin{array}{c}\text { Kerületi angol verseny } \\
\text { szervezése }\end{array}$ & $\begin{array}{l}\text { Alsó tagozatos } \\
\text { kerületi angol vers- } \\
\text { és mesemondó } \\
\text { verseny szervezése }\end{array}$ & $\begin{array}{l}\text { projektvezet } \\
\text { ö "Nyitott } \\
\text { világ" } \\
\text { vezető }\end{array}$ & $\begin{array}{c}2016 . \\
\text { november }\end{array}$ & 2016. november \\
\hline ஸ் & $\begin{array}{c}\text { Angliai kapcsolat } \\
\text { kiépitése }\end{array}$ & $\begin{array}{l}\text { Angliai testvériskolai } \\
\text { kapcsolat létrehozása }\end{array}$ & $\begin{array}{l}\text { intézményv } \\
\text { ezetö, } \\
\text { tagintéz- } \\
\text { mény- } \\
\text { vezetö, } \\
\text { "Nyitott } \\
\text { világ" } \\
\text { vezető }\end{array}$ & $\begin{array}{c}2016 . \\
\text { szeptember }\end{array}$ & 2017. szeptember \\
\hline
\end{tabular}




\begin{tabular}{|c|c|c|c|c|c|}
\hline$\stackrel{\oplus}{\Xi}$ & $\begin{array}{c}\text { Aziskola } \\
\text { mikrokörnyezete }\end{array}$ & $\begin{array}{c}\text { Az iskola épületének } \\
\text { és üdvarának } \\
\text { megújítása }\end{array}$ & $\begin{array}{l}\text { intézményv } \\
\text { ezetö, } \\
\text { tagintéz- } \\
\text { mény- } \\
\text { vezetô, } \\
\text { projektveze- } \\
\text { tő }\end{array}$ & $\begin{array}{c}2015 . \\
\text { szeptember } \\
1 .\end{array}$ & $\begin{array}{c}\text { 2017. december } \\
31 \text {. }\end{array}$ \\
\hline$\ddot{\oplus}$ & Iskolabelsö & & & & \\
\hline 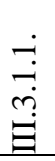 & $\begin{array}{c}\text { A folyosói vitrinek } \\
\text { átrendezése }\end{array}$ & $\begin{array}{l}\text { A vitrinek tartalmi } \\
\text { megújulása }\end{array}$ & $\begin{array}{c}\text { projektvezet } \\
\text { ő }\end{array}$ & $\begin{array}{c}2016 . \\
\text { június } \\
16 .\end{array}$ & $2016 . \quad$ július \\
\hline 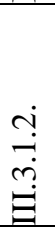 & A folyosók színesitése & $\begin{array}{c}\text { A folyosók } \\
\text { hangulatának } \\
\text { javulása }\end{array}$ & $\begin{array}{l}\text { intézményv } \\
\text { ezető, } \\
\text { tagintéz- } \\
\text { mény- } \\
\text { vezetö }\end{array}$ & $\begin{array}{c}2016 . \\
\text { június } \\
16 .\end{array}$ & $\begin{array}{c}\text { 2017. december } \\
31 \text {. }\end{array}$ \\
\hline$\stackrel{\leftrightarrow}{\oplus}$ & Iskolaudvar & & & & \\
\hline$\stackrel{\dot{\sim}}{\stackrel{\leftrightarrow}{m}}$ & $\begin{array}{c}\text { Mini kreszpark } \\
\text { kialakitása }\end{array}$ & $\begin{array}{l}\text { A betonos területen } \\
\text { rollerrel és } \\
\text { kerékpárral } \\
\text { használható } \\
\text { kreszpark kialakítása }\end{array}$ & $\begin{array}{c}\text { projektvezet } \\
\text { ö }\end{array}$ & $\begin{array}{l}2016 . \\
\text { június } \\
16 .\end{array}$ & $\begin{array}{l}\text { 2016. augusztus } \\
31 \text {. }\end{array}$ \\
\hline 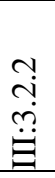 & $\begin{array}{l}\text { Iskolai játszótér } \\
\text { kialakitása }\end{array}$ & $\begin{array}{c}\text { Az elöírásoknak } \\
\text { megfelelö játszótér } \\
\text { kialakítása }\end{array}$ & $\begin{array}{l}\text { tagintéz- } \\
\text { mény- } \\
\text { vezető }\end{array}$ & $\begin{array}{c}2016 . \\
\text { január } \\
1 .\end{array}$ & $\begin{array}{l}\text { 2017. december } \\
31 \text {. }\end{array}$ \\
\hline
\end{tabular}

